\title{
Job Satisfaction and Organizational Commitment: Valid Predictors of Turnover Intentions
}

\author{
Uzma Aashiq a, Nargis Abbas ${ }^{b}$, Syed Salman Hassan c, Usman Riaz Mir ${ }^{\text {d }}$ \\ a Lecturer, Department of Social Work, University of Sargodha, Pakistan \\ Email: uzma.ashiq@uos.ed.pk \\ ${ }^{\mathrm{b}}$ Assistant Professor, Department of Education, University of Sargodha, Pakistan \\ Email: nargis.abbas@uos.edu.pk \\ c Deputy Director ORIC, Virtual University of Pakistan \\ ${ }^{d}$ Assistant Professor Management, University of Management \& Technology, Pakistan \\ Email: usman.riaz@skt.umt.edu.pk
}

\begin{tabular}{l}
\hline ARTICLE DETAILS \\
\hline History: \\
Accepted 17 Dec 2020 \\
Available Online 31 Dec 2020
\end{tabular}

Keywords:

Job Satisfaction, Organizational Commitment, Human Resource

Capital, Retention, Pakistan

JEL Classification: J28, D23, D29, E24

DOI: $10.47067 /$ reads.v6i4.292

\begin{abstract}
Human resource capital is the most strategic part of any organization. Retention of human resources is a critical issue these days. Keeping in view the importance of human capital and its retention, present study aimed to explore the impact of two strong predictors, job satisfaction and organizational commitment, on turnover intentions of employees in banking sector of Pakistan. 250 Survey questionnaires are distributed in Islamic and Conventional banks to elicit responses of professionals among which 207 questionnaires are returned and used for analysis. Findings reveal surprisingly contradictory results from previous studies. Job Satisfaction and organizational commitment are having very negligible impact on turnover intentions. Although employees are not much satisfied as well as committed with the organization but still they have minimal intention towards leaving the organization. Results indicated that turnover intentions of employees in banking sector of Pakistan depend on various other factors. Results are surprising but the paradox can be understood by keeping in view few demographics of respondents as well as the economic condition of the country. The study has significant decision-making implications forbanks and called for an urgently inquiry about those influential factors that largely affect the turnover intentions of their employees. In addition, banks also need to apply measures to enhance the job satisfaction and organizational commitment as empirical results indicate very less satisfaction and commitment of employees.
\end{abstract}

C2020 The authors. Published by SPCRD Global Publishing. This is an open access article under the Creative Commons Attribution-

NonCommercial 4.0

Corresponding author's email address: usman.riaz@skt.umt.edu.pk

\section{Introduction}

Firms depend on their eminent skilled employees to survive successfully with respect to market 


\section{Review of Economics and Development Studies, Vol. 6(4) 2020, 931 - 939}

transformations (Chen, Ployhart, Thomas, Anderson \& Bliese, 2011). Barney and Wright (1997) discussed that most corporations report annually that human resources are the most important assets. The authors also proposed that human resources also provide sustainable competitive advantage to the firm. They further elaborated that human resource is the only resource that can be called as valuable, rare, inimitable and nonsustainable.

A critical issue for the firms is the retention of employees (Chen, Ployhart, Thomas, Anderson \& Bliese, 2011). ). They depend on their eminent skilled employees to survive successfully with respect to market transformations (Chen, Ployhart, Thomas, Anderson \& Bliese, 2011). Banks, being the main contributors towards economic and financial development of the country, need to take care of the factors affecting turnover intentions of their employees; which might cause loss in the shape of human capital and low performance; especially in the period of high economic turmoil.

Turnover intention is a predictor of turnover (Chen, Hui \& Sego, 1998). Elangovan (2001) defined turnover intentions as "an attitudinal orientation or a cognitive manifestation of the behavioral intention to quit." Tett and Meyer (1993) defined turnover intentions as "the last in a sequence of withdrawal cognitions, a set to which thinking of quitting and intent to search for alternative employment also belongs."

Hausknecht and Trevor (2011) proposed that a large portion of the work created so far has centered either on voluntary turnover or on aggregate turnover reported through casual records to be generally voluntary. Literature supports two types of turnover, when an employee resigns from the organization; it is voluntary turnover and when it is made essential for an employee to resign then it is involuntary turnover (Lambert et al. 2012).

Turnover causes both direct and indirect costs to the organization (Collins, McKinnies, Matthews and Collins, 2015). The purpose of present study is to analyze an impact of two factors which are job satisfaction and organizational commitment on employees' turnover intentions in banking sector of Pakistan. Glisson \& Durick (1988) argued that job satisfaction and organizational commitment perform a key role in contributing towards the intentions of staying or leaving the organization.

Rayton (2006) researched that job satisfaction is one of the most profoundly researched employee demeanors in last half century. Spector (1997) noted that job satisfaction occurs when a person is happy with his/her job. This means that if a person likes his/her job then it leads to job satisfaction. This definition concerned with two broad ideas that whether the person is satisfied with overall job or not and whether the person is satisfied with some parts of job or not. Job satisfaction is concerned with multi dimensional psychological responses to one's job (Hulin \& Judge, 2003).

Organizational commitment is the relative power of a person's recognition and involvement in particular organization (Porter, Steers, Mowday, 1974; Steers, 1977). Miller (2003) defined organizational commitment as a state in which the employee of an organization identifies with it and its goals and wishes to be the part of that organization.

Organizational commitment is found in various forms. The form of organizational commitment that exists as a relationship between the organization and the employee is the attitudinal commitment. Grusky (1966) defined attitudinal commitment as the identification of an employee with the organization and its goals, and the willingness to continue the work in that particular organization to reach those goals, as well as the emotional commitment of employee towards the social system is attitudinal commitment.

Allen and Meyer (1990) showed differences in various definitions of attitudinal commitment, they measured each of them and showed different relationships with works done before. Classification of organizational commitment was done in three groups' named as affective-emotional commitment, continuance commitment and normative commitment (Meyer \& Allen, 1991). This study too has used these three kinds of organizational commitment as these are the mainly researched ones. Hence, organizational commitment has 


\section{Review of Economics and Development Studies, Vol. 6 (4) 2020, 931 - 939}

multidimensional constructs. The reason behind this is the relationship of an employee with the organization that shows different degrees of all three dimensions (Chelladurai, 2005). By examining various conceptualizations of organizational commitment, Meyer and Allen (1991) uncovered three different components. The first being affective commitment which a wish of an employee to remain in the organization resulting from the feelings of comfort and personal competence associated with work experiences in that organization. The second is the continuance commitment, which reflects the need of an individual to remain in his organization, resulting from recognition of costs that he would have to bear in case leaving that organization. The third component is normative commitment which is an employees' loyalty to his/her organization, includes repayment of favors received by an employee in that organization.

The study is very significant for the modern organizations today as it will help them to establish an understanding of how they can reduce the turnover intentions of their human capital by focusing on increasing their organizational commitment and job satisfaction levels or whether job satisfaction and job commitment are the real issues with respect to turnover intentions or not.

\section{Literature Review:}

Turnover causes both direct and indirect costs to the organization (Collins, McKinnies, Matthews and Collins, 2015). Turnover intentions among other predictors are the strongest predictor of actual turnover (Griffeth et al, 2000). Actual turnover is the direct outcome of turnover intentions but as the results suggested, the linkage is a tenuous one at organizational level (Cohen, Blake and Goodman, 2015). Lambert, Hogan and Barton (2001) discussed that turnover intentions is consistent with actual employee turnover because of which measuring this is the next best method. Hence the researchers rely on employee turnover intentions to measure actual employee turnover rate. Various other authors researched turnover intentions in banks as a dependent variable and considered different factors having influence on it (Gul, Rehman, Usman and Hussain, 2015; Akyuz, Kaya and OzGELDI,2015; Abbas, Raja, Darr and Bouckenooghe, 2014; Babakus, Yavas and Ashill, 2010)

Loi, Yang, \& Diefendorff (2009) linked job satisfaction to various important organizational variables, for example, productivity, absenteeism, and turnover. There is vast research on job satisfaction including various models and studies that enlighten the nature of job satisfaction (Locke, 1983). Many authors propose that the Hawthorne studies that happened in 1924 were the commencement of studying job satisfaction (Saari \& Judge, 2004: Petty, McGee \& Cavender, 1984).

Tlaiss and Mendelson (2014) studied job satisfaction in women and found that it is related to age, religious affiliation and tenure, not on marital status and education. George (2015) revealed from his findings that different sectors of banks had different levels of job satisfaction.

Khan, Aslam and Lodhi (2011) noting the importance of employees in an organization elaborated that employee are the building blocks of an organization. They further explained that for keeping the employees happy, to increase their satisfaction and to retain them, their salary must be adequate. Wyland, Lester, Ehrhardt and Standifer (2015) found the strongest antecedent of job satisfaction, interpersonal facilitation and job performance was work-school facilitation.

Business organizations which also include banks, which attain the loyalty of employees and customers, achieve high profits, they have better pays, and rewards structure and these are the ones who have retained their most talented and firm employees (Khan et al, 2011). Kuo, Lin and Li (2014) analyzed the job satisfaction levels of nurses in Taiwan and found that higher job satisfaction decreased the work stress and turnover intentions of long-term care nurses.

Singh (2014) analyzed the turnover intentions and job satisfaction of teachers of professional institutions and found that this sector had very high turnover intentions and there was a negative correlation between overall job satisfaction and turnover intentions. 
The dynamic nature of turnover intentions and job satisfaction has been discussed by Chen et al. (2011) by analyzing the changing levels of job satisfaction as well as turnover intentions level of employees at earlier period of time and then noting them again at different time intervals of their job. The results were found and there came a negative relationship between the two variables. The time when the job satisfaction level was high, turnover intentions were very low and by the time due to certain other factors when job satisfaction decreased, turnover intentions level raised. Hence Chen et al. (2011) explained that job satisfaction played a unique role in determining turnover decisions. Hence, the organized change over time in job satisfaction drives the turnover intentions change.

To find out the level of turnover intentions on the basis of job satisfaction, first hypothesis is formulated as follows:

H1: There is an impact of job satisfaction on turnover intentions in banking sector of Pakistan.

Suliman and Al- Junaibi (2010) studied affective and continous commitment with reference to turnover intentions in employees. The overall organizational commitment was negatively related to turnover intentions and affective commitment had more strong negative relationship with turnover intentions than continuous commitment. This study concluded that employees who are having strong affective commitment want to stay longer with the organization.

A research conducted by Zhao et al (2013) showed that high affective commitment turns turnover intention to be lower. Tett \& Meyer (1993) has linked organizational commitment to have a positive outcome as it is associated with decreased turnover intentions. They conducted a meta-analysis and found that there was a correlation of -0.54 between organizational commitment and turnover intentions. They also found that organizational commitment is the second strongest predictor of actual turnover while the first strongest predictor is intention to leave.

Another meta-analysis conducted by Mathieu \& Zajac (1990) also found that organizational commitment is highly correlated with turnover intentions. Organizational commitment is a tough predictor of search intentions as well as turnover intentions (Gautam, Dick \& Wagner, 2001). Gim, Desa and Ramayah (2015) took affective commitment and turnover intentions are negatively related.

Hence, it can be seen in above mentioned literature that organizational commitment has a negative relation with turnover intentions. If there is high organizational commitment then it leads to lower turnover intentions and if there is low organizational commitment then turnover intentions is high. However, to assess the level of turnover intentions due to various levels of organizational commitment following hypothesis is formulated:

H2: There is an impact of organizational commitment on turnover intentions in banking sector of Pakistan.

Mathieu, Fabi, Lacoursiere and Raymond (2015) noted that organizational commitment has a direct effect on turnover intentions. However, Camp (1994) presented that organizational commitment is having more impact on turnover intentions as compared to job satisfaction. The study revealed that the higher was the organizational commitment, the lower was turnover intentions and vice versa.

Abu Elanain (2009) conducted a research to examine impact of job characteristics and as expected from previous literature, he found that job satisfaction and organizational commitment was positively correlated and both of these variables were having negative association with turnover intentions. Hypothesis 1 tried to test the combined effect of both the independent variables on dependent variable as follows:

H3:There is an impactofjobsatisfaction andorganizationalcommitmentonturnoverintentions in banking sector of Pakistan.

\section{Methodology}

The study has focused on finding the impact of job satisfaction and organizational commitment on turnover intentions through the questionnaire survey method by using quantitative research approach. Positivist 
Review of Economics and Development Studies, Vol. 6(4) 2020, 931 - 939

paradigm is used by adopting statistical procedures to draw conclusions to support hypothesis of the research. The research is done on officers of different grades in Islamic and conventional banks of Lahore. Target population comprised of managerial and non- managerial positions. As the nature of study was quantitative, hence data was collected by using questionnaire. Data on job satisfaction, organizational commitment and turnover intentions was obtained on the basis of scales devised by Macdonald \& Maclntyre (1997), Meyer and Allen (2004) and Sjoberg and Sverke (2000) respectively. Convenience sampling technique is used so that the data can be easily collected from where it is conveniently available. The primary data from banks is collected through questionnaires. The unit of analysis consisted of banks' employees within Lahore, Pakistan. Hence, data is collected through self-administrated data collection technique. Two hundred and fifty questionnaires were given to be filled by the respondents and a total of 207 banking employees responded positively. To analyze the information, researcher used statistical techniques. Researcher used Statistical Package for the Social Science (SPSS) for codification, handling and calculation of data. The analysis must have normal data which means that the data collected should be normally distributed. Normality distribution is that assumption in which each variable and the linear combinations of variables observed are found normally distributed (Marcoulides \& Hershberger, 2014). To test the normality of the data Kolmogorov Smirnov test was used. The situation where the data drawn from a population has normal distribution is the normality of data (Ramzan, Zahid and Ramzan, 2013). Regression Analysis was used to estimate the impact of the variables more specifically the impact of two independent variables on dependent variable.

\subsection{Analysis}

Reliability of the instrument is verified with the help of Cronbach's alpha. In case of job satisfaction, Cronbach's alpha is 0.858 and in case of organizational commitment it is 0.757 . However turnover intentions, the dependent variable, had a reliability statistics of .824. Darren and Mallery (2003) noted that internal consistency of an instrument would be good if its alpha coefficient is greater than 0.8 and less than 0.9 . The reliability statistics of the complete instrument was .836.

The Descriptive statistic of the variables' is shown in Table as follows:

\subsubsection{Descriptive Statistics}

Table 01:Descriptive Statistics

\begin{tabular}{|l|c|c|c|}
\hline & N & Mean & $\begin{array}{l}\text { Standard } \\
\text { Deviation }\end{array}$ \\
\hline Job_Satisfaction & 207 & 3.4356 & 0.65238 \\
\hline Turnover_Intentions & 207 & 3.0998 & 0.55824 \\
\hline Organizational_Commitment & 207 & 3.2477 & 0.42326 \\
\hline
\end{tabular}

Simple linear regression is used to test the impact of job satisfaction and organizational commitment on turnover intentions of employees in banking sector of Pakistan. Normality is already checked through Kolmogorov Smirnov test with a conclusion that data is normal to further conduct the test for finding the impact of independent variables on dependent one.

To detect the presence of autocorrelation in the prediction errors Durbin- Watson statistic test is used. The statistic lies between 0 to 4 . If the statistic is 0 or closer to 0 then it means that it has positive autocorrelation whereas if the statistic comes 4 or closer to 4 then this shows negative correlation. However, the acceptable statistic of Durbin Watson should be from 1.7 to 2.4, which means that there is no autocorrelation. For the present study Durbin Watson has a statistic value of 2.2 which means that there is no auto correlation in the selected sample.

Multicollinearity is tested with the help of collinearity statistics in which VIF value greater than 10 and 


\section{Review of Economics and Development Studies, Vol. 6(4) 2020, 931 - 939}

tolerance less than 0.1 shows that there is serious problem regarding multicollinearity. O'Brien (2007) estimated in his research that tolerance of less than 0.20 or 0.10 or a Variance Inflation Factor of 5 or 10 and above indicates a multicollinearity issue. The Tolerance Value shown in the table for Job Satisfaction is 1.000 which shows that it is greater than 0.2 and 0.1 , so it is acceptable. Variance Inflation Factor, on the other hand, is also acceptable as its value is 1.000 which is also well within the acceptable range. Both tolerance and VIF show that there is no multicollinearity issue in the data. The results of analysis are as follows:

TABLE 2: MOdEL SUMMARY OF JOB SATISFACTION IMPACT ON TURNOVER INTENTIONS

\begin{tabular}{|c|c|c|c|c|c|c|c|c|c|}
\hline Model & $\mathrm{R}$ & R Square & $\begin{array}{c}\text { Adjusted R } \\
\text { Square }\end{array}$ & ANOVA Sig & $\begin{array}{l}\text { Durbin } \\
\text { Watson }\end{array}$ & $\begin{array}{l}\text { Unstandardize } \\
\text { d Coefficients }\end{array}$ & \multicolumn{2}{|c|}{$\begin{array}{c}\text { Collinearity } \\
\text { Statistics }\end{array}$} & \multirow[t]{2}{*}{ Constant } \\
\hline & & & & & & & Tolerance & VIF & \\
\hline 1 & -.179 & 0.032 & 0.027 & 0.00 & 2.2 & -0.263 & 1.000 & 1.000 & 4.002 \\
\hline
\end{tabular}

Turnover Intentions $=4.002+-.263$ (Job Satisfaction)

In this case $\mathrm{B}$ value is negative because job satisfaction has negative relation with turnover intentions. .263 unit changes in turnover intentions are affected by 1 unit change in job satisfaction. Negative sign marks the fact that more job satisfaction causes lesser turnover intentions and vice versa. Hypothesis 1 is accepted based on the results of regression analysis.

TABLE 03: MOdel SUMmary OF ORG. COMmitMent ON TURNOVER INTENTIONS

\begin{tabular}{|c|c|c|c|c|c|c|c|c|c|}
\hline Model & $\mathrm{R}$ & $\begin{array}{c}\mathrm{R} \\
\text { Square }\end{array}$ & $\begin{array}{l}\text { Adjusted } \\
\text { R Square }\end{array}$ & $\begin{array}{l}\text { ANOV } \\
\text { A Sig }\end{array}$ & $\begin{array}{l}\text { Durbin } \\
\text { Watson }\end{array}$ & $\begin{array}{c}\text { Unstandardized } \\
\text { Coefficients Beta } \\
\text { B }\end{array}$ & \multicolumn{2}{|c|}{$\begin{array}{l}\text { Collinearity } \\
\text { Statistics }\end{array}$} & Constant \\
\hline & & & & & & & Tolerance & VIF & \\
\hline 1 & -0.116 & 0.013 & 0.010 & 0.00 & 2.214 & -.261 & 1.000 & 1.000 & 4.003 \\
\hline
\end{tabular}

Turnover Intentions $=4.003+-.261$ (Organizational Commitment)

-.278 units change in turnover intentions are affected by 1 unit change in organizational commitment. Unstandardized coefficient B value shows -.261 values which denotes that organizational commitment has negative impact on turnover intentions. Hypothesis 2 is also accepted.

\section{TABLE 04: COEFFICIENTS}

\begin{tabular}{|l|l|l|l|}
\hline & Model Coefficients & Unstandardized & Collinearity Statistics \\
\hline & & B & Tolerance VIF \\
\hline Constant & 4.102 & & \\
\hline Job-Satisfaction & -.253 & 0.636 & 1.572 \\
\hline Org-Commitment & & 0.636 & 1.572 \\
\hline
\end{tabular}

Turnover Intentions $=4.102-.253$ (Job Satisfaction) -.03 (Organizational Commitment)

The equation depicts that turnover intentions has negative impact of job satisfaction and organizational commitment and -.253 units change in turnover intentions is caused by 1 unit change in job satisfaction and -..03 units change in turnover intentions is caused by 1 unit change in organizational commitment. 


\section{TABLE 05: MODELSUMMARY OF DEPENDENT ANDINDEPENDENT VARIABLES}

\begin{tabular}{|l|l|l|l|l|l|}
\hline Model & R & R Square & $\begin{array}{l}\text { Adjusted R } \\
\text { Square }\end{array}$ & $\begin{array}{l}\text { Durbin } \\
\text { Watson }\end{array}$ & $\begin{array}{l}\text { ANOVA } \\
\text { Sig }\end{array}$ \\
\hline 1 & -.180 & 0.032 & 0.023 & 2.198 & 0.035 \\
\hline
\end{tabular}

Based on the results of regression analysis hypothesis 3 is also accepted.

\section{Conclusion}

Analysis in this research showed a very negligible impact of job satisfaction and organizational commitment on turnover intentions. However, previous studies between these variables proved that job satisfaction has very strong relation with turnover intentions (Kuo, Lin and Li, 2014) and there is negative impact of organizational commitment on turnover intentions (Wong and Laschinger, 2015). The study revealed that impact of job satisfaction and organizational commitment on turnover intentions is low. These independent variables created $3.2 \%$ variation in turnover intentions. The study acknowledged certain limitations that provide an opportunity and suggestions for future research. Current study focused on job satisfaction and organizational commitment, other dimensions like HR practices, compensation plans, recognition etc. can also be investigated in the context of turnover intentions. In addition study can also be incorporated in diverse industries and cities. On the other hand, the current study has been conducted by using convenience sampling, which is non-probability sampling. Getting a larger data was difficult for the researcher.

The present study investigated the banking sector of Lahore, Pakistan. Researcher should take into account different sectors and organizations. To maximize result's generalizability, researcher may increase the size of sample from the same or different sector for future research.

Qualitative research can also be done to look for the factors that have more strong impact on turnover intentions. However, other dominant factors can also be researched.

If research can be conducted on different sectors, then a comparison can also be made for the results. For example, a researcher can make a comparison between banking sector and educational sector of Pakistan involving other major cities too.

The study has certain implications including the first one as Lahore is a major and famous city of Pakistan, where all types of banks are doing their business operations. Hence researcher has tried to include respondents from majority of the banks as it is very important for the banks to know about their employee's state of staying or leaving their organizations so as to take necessary measures to keep their valuable human capital.

As the results show, job satisfaction and organizational commitment has a very small impact on turnover intentions hence banks should take into notice other variables in order to avoid turnover of their employees. These results are not only surprising for researchers but also alarming for banks as they are in need to search for the reasons that why the employees are having low job satisfaction and organizational commitment. Banks can take measures to check if employees are frustrated or are giving low productivity as employees' job satisfaction and organizational commitment is low. However, the study also gives a good hint to banks that their employees don't want to leave them. The study is very significant as it has bring into notice such things for banks which are very beneficial for them as they can take precautionary measures so that they may face no trouble in future of their business.

\section{References:}

Abbas, M., Raja, U., Darr, W., \& Bouckenooghe, D. (2014). Combined effects of perceived politics and psychological capital on job satisfaction, turnover intentions, and performance. Journal of Management, 40(7), 1813-1830. 
Review of Economics and Development Studies, Vol. 6 (4) 2020, 931 - 939

Abu Elanain, H. M. (2009). Job characteristics, work attitudes and behaviors in a non-western context: Distributive justice as a mediator. Journal of Management Development, 28(5), 457-477.

Akyuz, B., Kaya, N., \& Ozgeldi, M. (2015). The effects of human resource management practices and organizational climate on turnover intention: An empirical study in Turkish Banking Sector. IIB International Refereed Academic Social Sciences Journal, 17(6), 48.

Babakus, E., Yavas, U., \& Ashill, N. J. (2010). Service worker burnout and turnover intentions: Roles of person-job fit, servant leadership, and customer orientation. Services Marketing Quarterly, 32(1), 17-31.

Behson, S. J. (2005). The relative contribution of formal and informal organizational work-family support. Journal of Vocational Behavior, 66(3), 487-500.

Chen, G., Ployhart, R. E., Thomas, H. C., Anderson, N., \& Bliese, P. D. (2011). The power of momentum: A new model of dynamic relationships between job satisfaction change and turnover intentions. Academy of Management Journal, 54(1), 159-181.

Chelladurai, P. (2005). Managing organizations for sport and physical activity: A systems perspective. Holcomb Hathaway Publishers.

Cohen, G., Blake, R. S., \& Goodman, D. (2015). Does Turnover Intention Matter? Evaluating the Usefulness of Turnover Intention Rate as a Predictor of Actual Turnover Rate. Review of Public Personnel Administration, 1-24

Collins, S. K., McKinnies, R. C., Matthews, E. P., \& Collins, K. S. (2015). A Ministudy of Employee Turnover in US Hospitals. The health care manager, 34(1), 23-27.

Darren, G., \& Mallery, P. (2003). SPSS for Windows step by step: A simple guide and reference. 11.0 update. Boston: Allyn \& Bacon.

George, E. (2015). Job related stress and job satisfaction: A comparative study among bank employees. Journal of Management Development, 34(3), 316-329.

Gim, G. C., Desa, N. M., \& Ramayah, T. (2015). Competitive Psychological Climate and Turnover Intention with the Mediating Role of Affective Commitment. Procedia-Social and Behavioral Sciences, 172, 658-665.

Gul, H., Rehman, Z., Usman, M., \& Hussain, S. (2015). The Effect of Organizational Justice on Employee Turnover Intention with the Mediating role of Emotional Exhaustion in the Banking Sector of Afghanistan. International Journal of Management Sciences, 5(4), 272285.

Hausknecht, J. P., \& Trevor, C. O. (2011). Collective turnover at the group, unit, and organizational levels: Evidence, issues, and implications. Journal of Management, 37(1), 352-388.

Hulin, C. L., \& Judge, T. A. (2003). Job attitudes. Handbook of psychology. Two. 255-276.

Kipkebut, D. J. (2010). Organisational commitment and job satisfaction in higher educational institutions: The Kenyan case (Doctoral dissertation, Middlesex University).

Khan, R. I., Aslam, H. D., \& Lodhi, I. (2011). Compensation Management: A strategic conduit towards achieving employee retention and Job Satisfaction in Banking Sector of Pakistan. International journal of human resource studies, 1(1), 89-97.

Kuo, H. T., Lin, K. C., \& Li, I. (2014). The mediating effects of job satisfaction on turnover intention for long-term care nurses in Taiwan. Journal of nursing management, 22(2), 225233.

Lambert, E. G., Cluse-Tolar, T., Pasupuleti, S., Prior, M., \& Allen, R. I. (2012). A test of a turnover intent model. Administration in Social Work, 36(1), 67-84.

Loi, R., Yang, J., \& Diefendorff, J. M. (2009). Four-factor justice and daily job satisfaction: a multilevel investigation. Journal of Applied Psychology, 94(3), 770-781.

Marcoulides, G. A., \& Hershberger, S. L. (2014). Multivariate statistical methods: A first course: 
Review of Economics and Development Studies, Vol. 6 (4) 2020, 931 - 939

Psychology Press.

Mathieu, C., Fabi, B., Lacoursière, R., \& Raymond, L. (2015). The role of supervisory behavior, job satisfaction and organizational commitment on employee turnover. Journal of Management \& Organization, 1-17.

Meyer, J. P., \& Allen, N. J. (2004). TCM employee commitment survey academic users guide 2004. London, Ontario, Canada: The University of Western Ontario, Department of Psychology.

O'Brien, R. M. (2007). A caution regarding rules of thumb for variance inflation factors. Quality \& Quantity, 41(5), 673-690.

Peltokorpi, V., Allen, D. G., \& Froese, F. (2015). Organizational embeddedness, turnover intentions, and voluntary turnover: The moderating effects of employee demographic characteristics and value orientations. Journal of Organizational Behavior, 36(2), 292-312.

Ramzan, S., Zahid, F. M., \& Ramzan, S. (2013). Evaluating Multivariate Normality: A Graphical Approach. Middle East Journal of Scientific Research, 13(2). 254-263.

Rayton, B. A. (2006). Examining the interconnection of job satisfaction and organizational commitment: an application of the bivariate probit model. The International Journal of Human Resource Management, 17(1), 139-154.

Saari, L. M., \& Judge, T. A. (2004). Employee attitudes and job satisfaction. Human resource management, 43(4), 395-407.

Singh, K. (2014). Impact of Job Satisfaction on Turnover Intentions of college teachers of professional institutions in Punjab. Golden Research Thoughts, 3(11). 1-6.

Suliman, A. M., \& Al Obaidli, H. (2011). Organizational climate and turnover in Islamic banking in the UAE. International Journal of Islamic and Middle Eastern Finance and Management, 4(4), 308-324.

Suliman, A. A., \& Al-Junaibi, Y. (2010). Commitment and turnover intention in the UAE oil industry. The International Journal of Human Resource Management, 21(9), 1472-1489.

Tlaiss, H. A., \& Mendelson, M. B. (2014). Predicting women's job satisfaction with personal demographics: Evidence from a Middle Eastern country. The International Journal of Human Resource Management, 25(3), 434-458.

Wasti, S. A. (2003). The influence of cultural values on antecedents of organisational commitment: an individual-level analysis. Applied Psychology,52(4), 533-554.

Wong, C. A., \& Laschinger, H. K. S. (2015). The influence of frontline manager job strain on burnout, commitment and turnover intention: A cross-sectional study. International journal of nursing studies, 52(12), 1824-1833.

Wyland, R., Lester, S. W., Ehrhardt, K., \& Standifer, R. (2015). An Examination of the Relationship Between the Work-School Interface, Job Satisfaction, and Job Performance. Journal of Business and Psychology, 1-17.

Zhao, X., Sun, T., Cao, Q., Li, C., Duan, X., Fan, L., \& Liu, Y. (2013). The impact of quality of work life on job embeddedness and affective commitment and their co-effect on turnover intention of nurses. Journal of clinical nursing, 22(5-6), 780-788. 